Reprinted from Agronomy ,ournal

Vol. 76, Jan.-Feb. 1984

\title{
Heat Stress Effects on Protein Synthesis and Exosmosis of Cell Solutes in Three Turfgrass Species ${ }^{1}$
}

\section{J. Wehner and T. L. Watschke ${ }^{2}$}

\begin{abstract}
Kentucky bluegrass (Poa pratensis L.), annual bluegrass (Poa annua L.), and perennial ryegrass (Lolium perenne L.) differ in their heat tolerance as determined by piant dry weight 2 weeks after exposure to heat stress. The status of the plants at that time depends on the degree of injury that occurs during the stress treatment and the repair or tolerance of that injury. The purpose of this research was to evaluate species differences in the degree of initial injury due to heat stress. The incorporation of radio-labeled leucine as an indicator of the net rate of protein synthesis and the efflux of cell solutes from plant tissue sections into distilled water were evaluated immediately after turfgrass shoots or tissue sections were exposed to temperatures in the range of 43 to $51{ }^{\circ} \mathrm{C}$ for $30 \mathrm{~min}$. Net protein synthesis in the grasses was very heat labile. Incorporation of radiolabeled leucine declined an average of $69 \%$ in plants previously heated at $43{ }^{\circ} \mathrm{C}$ compared to plants held at $27^{\circ} \mathrm{C}$. Eflux of cell solutes from the tissue sections did not increase in plants that had been heated to $43,45,47$, or $49{ }^{\circ} \mathrm{C}$ compared to plants held at 25 ${ }^{\circ} \mathrm{C}$. No significant differences were found between the grasses for the parameters tested. Either disruption of some other physiological process or differential repair or tolerance of the heat stress injury accounted for the heat tolerance rankings of the grasses. Also, the results of this study indicate that indirect rather than direct heat injury is responsible for the behavior of the grasses stressed at the temperatures and exposure periods used in this study.
\end{abstract}

Additional index words: Kentucky bluegrass (Poa pratensis L.), Perennial ryegrass (Lolium perenne L.), Annual bluegrass (Poa annua L.), Stress physiology.
TuRfgrass species and cultivars within species dif1 fer in the ability to tolerate exposure to short periods of high temperature (direct heat stress). In previously reported research, Wehner and Watschke (1981) found that Kentucky bluegrass (Poa pratensis L.) was more heat tolerant than perennial ryegrass (Lolium perenne L.) and annual bluegrass (Poa annua L.). Furthermore, among the perennial ryegrass cultivars tested, 'Pennfine' was more heat tolerant than 'Loretta', Heat tolerance rankings were based on the weight of heat-stressed plants compared to the weight of nonstressed controls 2 weeks after exposure to temperatures in the range of 42 to $47^{\circ} \mathrm{C}$ for $30 \mathrm{~min}$.

The status of plants after a recovery period depends on the amount of injury which occurred during the heat stress treatment and the repair or tolerance of that injury. The purpose of this research was to determine if differences exist in the amount of initial

'Contribution of the Pennsylvania Agric. Exp. Stn., University Park, PA. Journal Series No. 6649. Received I Apr, 1983. Published in Agron. J. 76:16-19.

${ }^{2}$ Assistant professor of turfgrass science, Horticulture Dep., Univ. of llinois. Urbana, and professor of turfgrass science, The Pennsylvania State Univ,. University Park, PA. 
injury to Kentucky bluegrass, annual bluegrass, and perennial ryegrass exposed to high temperature. Two physiological parameters, incorporation of radiolabeled leucine as an indicator of the net rate of protein synthesis and exosmosis of cell solutes, were measured immediately after stress treatment.

The rate of protein synthesis in plants can be reduced by both heat and drought stress (Dhindsa and Cleland, 1975; Weidner and Ziemens, 1975). In drought-stressed oat coleoptiles, there was both a quantitative and qualitative change in protein synthesis (Dhindsa and Cleland, 1975). The decrease in synthesis rate was attributed to a reduction in the amount of polyribosomes in the cells. Weidner and Ziemens (1975) measured incorporation of radioactive leucine while heating excised wheat shoots which had been grown at several different temperature regimes. The degree of reduction in net synthesis rate depended on the intensity of the stress and the preconditioning temperature. The plants maintained highest synthesis rates when heated at temperatures similar to those at which they were preconditioned. Heat tolerant plants must be able to resist heat induced protein denaturation injury or replace damaged proteins (Levitt, 1980). The synthesis rate after stress treatment may indicate the amount of injury to the plant as well as the potential for recovery.

Efflux of solutes from plant cells has been used as an indicator of relative injury in screening tests for both heat (Sullivan, 1971) and cold (Dexter et al., 1932) tolerance. The tests are based on a correlation between the loss of solutes from heated or frozen tissue and plant recovery from similar stress conditions. Solute loss is determined by measuring the conductivity of a solution in contact with the treated tissue. Martineau et al. (1979) used this technique to study high temperature tolerance in soybeans while Wallner et al. (1982) have used the technique as a measure of turfgrass heat tolerance in vitro.

\section{MATERIALS AND METHODS \\ Plant Material}

Seeds of 'Pennstar' and 'Sydsport' Kentucky bluegrass, 'Pennfine' and 'Loretta' perennial ryegrass, and annual bluegrass (native selection from State College, $\mathrm{Pa}$.) were planted in $11 \mathrm{~cm}$ pots containing a Hagerstown silt loam soil (fine, mixed, mesic Typic Hapludalf) with a $\mathrm{pH}$ of 7.0 and with 93 and $325 \mathrm{~kg}$ ha available $\mathrm{P}$ and $\mathrm{K}$, respectively. After 6 weeks, the plants were thinned to 60 pot $^{-1}$ and each pot was fertilized with $37 \mathrm{mg} \mathrm{NH} \mathrm{NO}_{3}$ and brought to $26 \%$ soil moisture by weight. They were then placed in a growth chamber set for $12-\mathrm{h}$ days $\left(285 \mu \mathrm{E} \mathrm{m} \mathrm{m}^{-2} \mathrm{~s}^{-1}\right.$ PAR $)$ ) at $27^{\circ} \mathrm{C}$ and a night temperature of $16^{\circ} \mathrm{C}$. The plants were maintained in the growth chamber for 5 weeks during which time the pots were allowed to dry to $11 \%$ soil moisture by weight before rewatering. After 4 weeks, some of the plant material was used for the heat stress-recovery tests reported earlier (Wehner and Watschke, 1981). The remaining plant material was maintained in the growth chamber for an additional week and was used for the heat stress-physiological tests. Twentyfour hours prior to each of the physiological experiments, the pots were brought to the same weight (approximately $18 \%$ soil moisture). In these tests, the experimental unit was a pot of the given cultivar. A second set of plants was started 1 month later than the first. These plants were treated as described above to provide additional material for the physiological experiments.

\section{Incorporation of Radioactive Leucine}

Ten shoots of each cultivar were heated for $30 \mathrm{~min}$ in plastic bags at $27,43,45$, and $47^{\circ} \mathrm{C}$ (three replications at each temperature) in a water bath. Immediately after heating, the shoots were placed in $10 \mathrm{ml}$ of $5 \mathrm{mM}$ phosphate buffer, pH 7.0, containing $2 \mu \mathrm{Cr}$ of ${ }^{14} \mathrm{C}$ (UL) leucine at 27 ${ }^{\circ} \mathrm{C}$ for $60 \mathrm{~min}$. Labeling was done in room light. The shoots were then rinsed with buffer, immersed in liquid $\mathrm{N}$, lyophilized, and ground in a ball mill. The ground tissue was extracted three times with hot $80 \%$ ethanol, once with hot $5 \%$ trichloroacetic acid, and once with acetone. After the tissue dried at room temperature, the labeled protein was solubilized with $1 \mathrm{~N} \mathrm{NaOH}$ at $37^{\circ} \mathrm{C}$ overnight. An aliquot of the resulting solution was used for protein determination by the method of Lowry et al. (1951). Radioactivity of the solubilized protein was assessed by liquid scintillation counting techniques using New England Nuclear Formula 963 cocktail. Quench correction was by the internal standard method. All results were expressed as a percentage of the radioactivity incorporated by the control $\left(27^{\circ} \mathrm{C}\right)$ per milligram of protein.

A second labeling experiment utilized only 'Sydsport' Kentucky bluegrass and 'Pennfine' and 'Loretta' perennial ryegrass. Plants for this experiment came from the group of pots started 1 month later. After heating the plants at either 27 or $43^{\circ} \mathrm{C}$ (temperatures chosen on the basis of the first experiment), they were placed in $5 \mathrm{ml}$ of $5 \mathrm{mM}$ phosphate buffer containing $8 \mu \mathrm{Cr}$ of ${ }^{3} \mathrm{H}(2,3)$ leucine at $27{ }^{\circ} \mathrm{C}$ for 60 min. The plants were then extracted and the amount of labeling determined as previously described. Five replications were used in this experiment.

\section{Efflux of Cell Solutes}

Five plants of each cultivar were removed from the soil, stripped of dead leaves, and had their roots trimmed to the base of the crown. The plants were cut into $3 \mathrm{~mm}$ sections, washed with deionized water, and tested for heat tolerance according to the procedure of Sullivan (1971). Three replications (five plants per replication) for each cultivar were heated at $25,43,45,47,49$, and $51{ }^{\circ} \mathrm{C}$ for $30 \mathrm{~min}$. The percent injury was calculated by the equation

$\%$ injury $=(100-\mathrm{Cl} / \mathrm{C} 2)$ heated sections $\times 100$

$(100-\mathrm{Cl} / \mathrm{C} 2)$ control $(25 \mathrm{C})$ sections

where $\mathrm{Cl}$ and $\mathrm{C} 2$ are the conductivities before and after boiling the tissue as prescribed by Sullivan (1971).

The results of the protein synthesis and solute efflux experiments were subjected to an analysis of variance using a randomized complete block design. When a significant $F$ ratio was found for a treatment effect, an LSD was calculated.

\section{RESULTS AND DISCUSSION}

\section{Incorporation of Labeled Leucine}

There was an average $69 \%$ decline in the incorporation of labeled leucine into plants that had been exposed to $43{ }^{\circ} \mathrm{C}$ relative to the nonstressed controls (Table 1). Using the amount of incorporation as an indicator of the net rate of protein synthesis leads to the conclusion that protein synthesis or factors affecting it were very heat labile. At $45{ }^{\circ} \mathrm{C}$, incorporation averaged $10 \%$ of the control. Similar results were found at $47^{\circ} \mathrm{C}$. However, since very little leucine was incorporated into plants heated at 45 or $47^{\circ} \mathrm{C}$, resulting in samples which had activity only slightly above 
Table 1. Net protein synthesis, recovery weights, and injury for five grasses after exposure to temperatures in the range of 43 to $51{ }^{\circ} \mathrm{C}$ for $30 \mathrm{~min}$.

\begin{tabular}{|c|c|c|c|c|c|c|c|c|c|c|c|c|c|}
\hline \multirow[b]{2}{*}{ Species and cultivar } & \multicolumn{13}{|c|}{ Temperature } \\
\hline & 43 & 45 & 47 & 43 & 45 & 47 & 49 & & 43 & 45 & 47 & 49 & 51 \\
\hline & \multicolumn{3}{|c|}{$\begin{array}{l}\text { Net protein synthesis } \\
\text { (\% of control) }\end{array}$} & \multicolumn{4}{|c|}{$\begin{array}{l}\text { Recovery weight } \neq \\
\text { (\% of control) }\end{array}$} & $\underset{42-47}{\bar{X}}$ & \multicolumn{5}{|c|}{ Injury $(1 \%)$} \\
\hline $\begin{array}{l}\text { Poa pratensis } \\
\text { Sdysport } \\
\text { Pennstar }\end{array}$ & $\begin{array}{l}37 \\
36\end{array}$ & $\begin{array}{l}14 \\
12\end{array}$ & $\begin{array}{l}8 \mathrm{~B} \dagger \\
8 \mathrm{~B}\end{array}$ & $\begin{array}{l}97 \mathrm{~A} \\
90 \mathrm{~A}\end{array}$ & $\begin{array}{l}70 \mathrm{~A} \\
65 \mathrm{AB}\end{array}$ & $\begin{array}{l}40 \mathrm{~A} \\
38 \mathrm{~A}\end{array}$ & $4 \$$ & $\begin{array}{l}74 \mathrm{~A} \\
70 \mathrm{~A}\end{array}$ & $\begin{array}{l}3 \\
3\end{array}$ & $\begin{array}{l}2 \\
2\end{array}$ & $\begin{array}{l}3 \\
3\end{array}$ & $\begin{array}{r}7 \\
11\end{array}$ & $\begin{array}{l}20 \mathrm{~B} \\
32 \mathrm{~A}\end{array}$ \\
\hline Poa annua & 25 & 9 & $5 \mathrm{~B}$ & $70 \mathrm{~B}$ & $50 \mathrm{AB}$ & $3 \mathrm{~B}$ & 0 & $51 \mathrm{~B}$ & 4 & 1 & 4 & 10 & $30 \mathrm{AB}$ \\
\hline $\begin{array}{l}\text { Lolium perenne } \\
\text { Pennfine } \\
\text { Loretta }\end{array}$ & $\begin{array}{l}22 \\
34 \\
\text { NS }\end{array}$ & $\begin{array}{r}7 \\
10 \\
\text { NS }\end{array}$ & $\begin{array}{r}6 \mathrm{~B} \\
14 \mathrm{~A}\end{array}$ & $\begin{array}{l}83 \mathrm{AB} \\
72 \mathrm{~B}\end{array}$ & $\begin{array}{l}47 \mathrm{~B} \\
24 \mathrm{C}\end{array}$ & $\begin{array}{r}11 \mathrm{~B} \\
3 \mathrm{~B}\end{array}$ & $\begin{array}{l}1 \\
0\end{array}$ & $\begin{array}{l}57 \mathrm{~B} \\
38 \mathrm{C}\end{array}$ & $\begin{array}{c}5 \\
7 \\
\text { NS }\end{array}$ & $\begin{array}{c}4 \\
2 \\
\text { NS }\end{array}$ & $\begin{array}{c}3 \\
4 \\
\text { NS }\end{array}$ & $\begin{array}{l}12 \\
10 \\
\text { NS }\end{array}$ & $\begin{array}{l}36 \mathrm{~A} \\
37 \mathrm{~A}\end{array}$ \\
\hline
\end{tabular}

$\dagger$ Means followed by a letter in common are not significantly different by the FLSD test at $P=0.05$.

$\ddagger$ Recovery weight data from Wehner and Watschke (1981).

Recovery weights for $49^{\circ} \mathrm{C}$ not analyzed.

1 Injury calculated from exosmosis of cell solutes according to the method of Sullivan (1971).

background, the values at these two temperatures should be considered approximate. Significant differences in incorporation were found only at $47^{\circ} \mathrm{C}$.

The recovery weights for plants heated at $43,45,47$, and $49^{\circ} \mathrm{C}$ and the mean recovery weight for the temperature range 42 to $47{ }^{\circ} \mathrm{C}$ (data from Wehner and Watschke, 1981) are included in Table 1 for comparison purposes. The recovery weight for Sydsport heated to $43^{\circ} \mathrm{C}$ was $97 \%$ of the control while for Loretta it was only $72 \%$ of the control. This is contrary to what might be expected from the incorporation data which indicated an equal decline in net synthesis rate in both cultivars. The weight reduction in the plants given the heat tolerance test at $43^{\circ} \mathrm{C}$ was due to reduced growth (compared to the control) during the recovery period. There was no browning or loss of leaves at $43^{\circ} \mathrm{C}$ as there was at higher temperatures. The decrease in net synthesis rate immediately after heat treatment as indicated by ${ }^{14} \mathrm{C}$ leucine incorporation was not a good measure of relative heat tolerance. The second labeling experiment agreed with the earlier labeling experiment. Leucine incorporation for Sydsport, Pennfine, and Loretta was respectively 30,23 , and $32 \%$ of the control.

\section{Efflux of Cell Solutes}

The injury data from the exosmosis test did not agree with the results of the heat tolerance screening using recovery weights (Table 1 ). The degree of tissue injury indicated by the conductivity test was slight in plants heated at 43,45 , and $47^{\circ} \mathrm{C}$. The corresponding recovery weights showed a steady decrease over this temperature range, with Poa annua and Loretta exhibiting little recovery at $47^{\circ} \mathrm{C}$.

At 49 and $51{ }^{\circ} \mathrm{C}$, the conductivity values increased with statistically significant differences among cultivars at $51{ }^{\circ} \mathrm{C}$. Sydsport was injured the least at $51^{\circ} \mathrm{C}$ as might be expected since it was the most heat tolerant. Poa annua was not significantly different from Sydsport while the other three cultivars were injured more than Sydsport. The injury values at $51{ }^{\circ} \mathrm{C}$ for Sydsport and Pennstar corresponded to their heat tolerance rankings, the injury values for Pennfine, $P o a$ annua, and Loretta did not. Based on the results of the exosmosis test, it was concluded that differential membrane injury among cultivars did not account for the recovery weights of the grasses.

The results of the incorporation and exosmosis experiments led to similar conclusions regarding the heat tolerance of the grasses chosen for study. Differences in the amount of initial injury as measured by these two parameters did not correspond to the recovery rankings. Two main possibilities exist to help explain the results of this research. The tolerance or repair of the injury that occurred may have been more important in determining the overall outcome of the heat tolerance screening or there may have been differential initial injury to some other metabolic process not evaluated in this study.

Levitt (1980) describes the mechanisms for injury by direct heat stress as denaturation of proteins and lipid phase transitions in the plasmalemma which can result in loss of cell contents. There were no differences in the amount of injury among the grasses for the parameters tested. This may indicate that the plants were not injured by direct heat stress but underwent indirect heat injury. This disagrees with a statement in our previous report (Wehner and Watschke, 1981), where we attributed the death of annual bluegrass after being exposed to 45 and $47{ }^{\circ} \mathrm{C}$ for $30 \mathrm{~min}$ to direct heat injury. Fischer (1967) found that a 2 -h exposure to $42{ }^{\circ} \mathrm{C}$ was lethal to Poa annua and also attributed these results to direct heat injury. Evidence that indirect injury was responsible for the reduced recovery weights in the heat stress tests is provided by Wallner et al. (1982). They found that plant tissue sections did not undergo a $50 \%$ loss (the figure used to indicate death of the tissue) of cell solutes until they had been heated at $50{ }^{\circ} \mathrm{C}$ for $150 \mathrm{~min}$ or $55^{\circ} \mathrm{C}$ for $20 \mathrm{~min}$. Wallner et al. (1982) did not use any whole plants in their research. Since cool-season turfgrasses can be killed by exposure to 47 to $49^{\circ} \mathrm{C}$ for only $30 \mathrm{~min}$ (Wehner and Watschke, 1981), it would appear that indirect injury was involved in our research. Indirect injury can be due to several different types of metabolic disruption (Levitt, 1980). According to Levitt (1980), the difference between direct and indirect heat stress is the length and intensity of the stress period. Short periods (a few seconds or minutes) at very high temperatures result in direct heat stress injury while 
long periods (several hours or days) at moderately high temperatures result in indirect heat stress injury. A dose-time study is needed to adequately characterize the type of injury that occurred in the cool-season turfgrasses used in our research.

\section{REFERENCES}

Dexter, S.T., W.E. Tottingham, and L.F. Graber. 1932. Investigations of the cold hardiness of plants by measurements of electrical conductivity. Plant Physiol. 7:63-68.

Dhindsa, R.S., and R.E. Cleland. 1975. Water stress and protein synthesis. I. Differential inhibition of protein synthesis. Plant Physiol. 55:778-781.

Fischer, J.A. 1967. An evaluation of high temperature effects on annual bluegrass (Poa annua L.). M.S. Thesis, Michigan State Univ., East Lansing.

Levitt, J. 1980. Responses of plants to environmental stresses. I.
Chilling, freezing, and high temperature stresses. Academic Press, New York.

Lowry, O.H., N.J. Rosebrough, L.J. Farr, and R.J. Randall. 1951. Protein measurement with the Folin phenol reagent. J. Biol. Chem. 193:265-275

Martineau, J.R., J.E. Sprecht, J.H. Williams, and C.Y. Sullivan 1979. Temperature tolerance in soybeans. I. Evaluation of a technique for assessing cellular membrane thermostability. Crop Sci. 19:75-78.

Sullivan, C.Y. 1971. Mechanisms of heat and drought resistance in grain sorghum and methods of measurement. p. 247-274. N.G.P Rao and L. House (ed.) In Sorghum in the Seventies. Oxford and IBH, New Delhi.

Wallner, S.J., J.R. Becwar, and J.D. Butler. 1982. Measurement of turfgrass heat tolerance in vitro. J. Am. Soc. Hortic. Sci. 107:608613.

Wehner, D.J., and T.L. Watschke. 1981. Heat tolerance of Kentucky bluegrasses, perennial ryegrasses, and annual bluegrass. Agron. J. 73:79-84.

Weidner, M., and C. Ziemans. 1975. Preadaption of protein synthesis in wheat seedlings to high temperature. Plant Physiol. 56:590-594. 